DOE/ID-10742 (2003)

February 2004

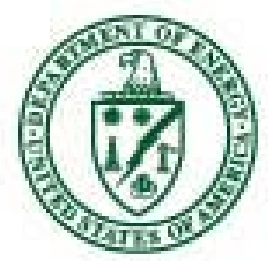

U.S. Department of Energy Idaho Operations Office

\title{
Annual Radiological Environmental Monitoring Program Report for the Fort St. Vrain Independent Spent Fuel Storage Installation
}




\title{
Annual Radiological Environmental Monitoring Program Report for the Fort St. Vrain Independent Spent Fuel Storage Installation
}

\author{
J. R. Newkirk \\ F. J. Borst, CHP
}

Published February 2004

Idaho National Engineering and Environmental Laboratory Idaho Nuclear Technology and Engineering Center Idaho Falls, Idaho 83415

Prepared for the

U. S. Department of Energy Assistant Secretary for Environmental Management Under DOE Idaho Operations Office

Contract DE-AC07-99ID13727 


\begin{abstract}
This report presents the results of the 2003 Radiological Environmental Monitoring Program conducted in accordance with 10 CFR 72.44 for the Fort St. Vrain Independent Spent Fuel Storage Installation. A description of the facility and the monitoring program is provided. The results of monitoring the predominant radiation exposure pathway, direct radiation exposure, indicate the facility operation has not contributed to any increase in the estimated maximum potential dose commitment to the general public.
\end{abstract}




\section{SUMMARY}

The purpose of this report is to present the results of the Radiological Environmental Monitoring Program (REMP) conducted during 2003 for the Fort St. Vrain (FSV) Independent Spent Fuel Storage Installation (ISFSI). The results of the thermoluminescent dosimetry network did not indicate an increase in radiation levels above post-loading ambient background attributed to the facility operation. The monitoring program results support the conclusion reached in the Safety Analysis Report that operation of the facility will not result in a significant dose commitment greater than $0.15 \mathrm{mrem} / \mathrm{y}$ to the nearest resident. 


\section{CONTENTS}

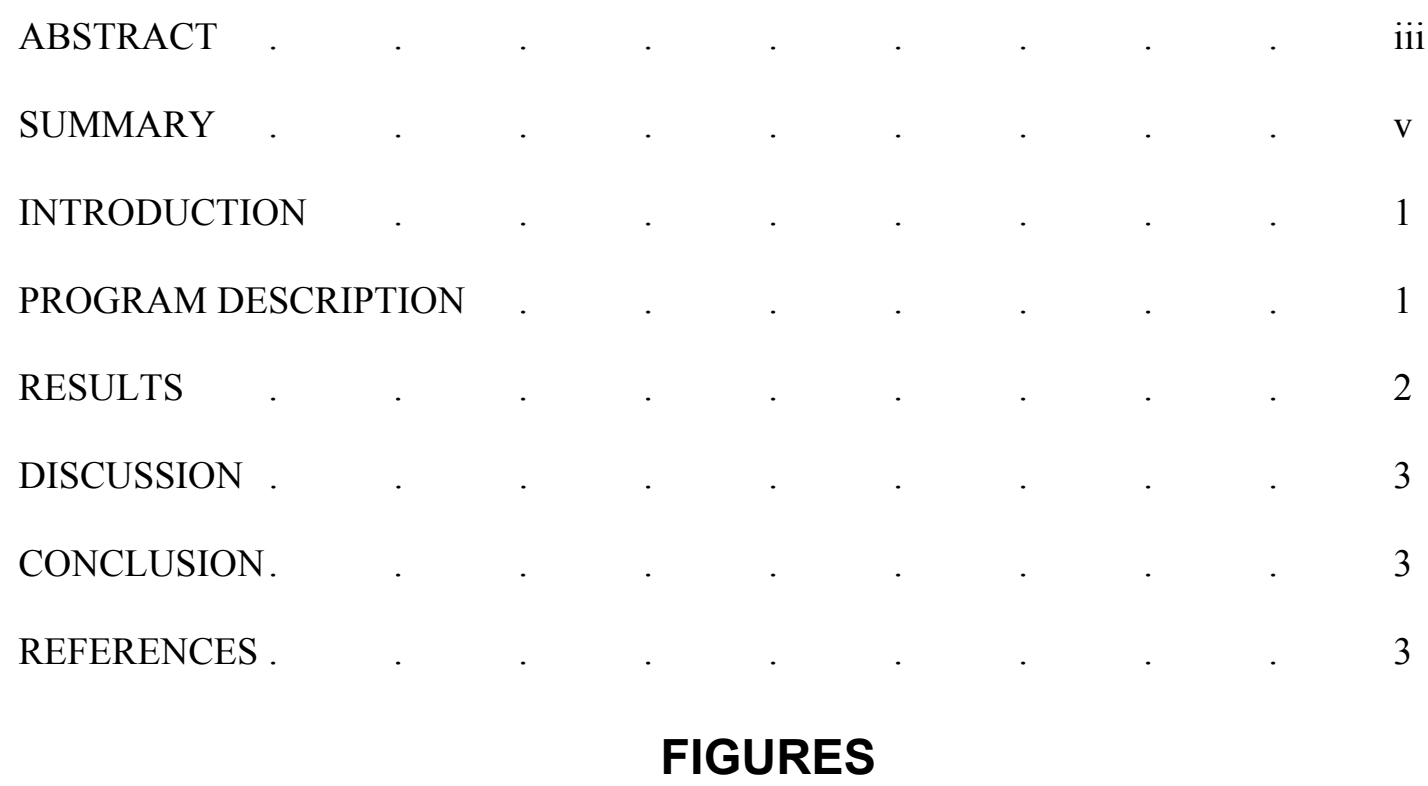

1. FSV ISFSI Radiological Environmental Monitoring Locations . . 1

\section{TABLES}

1. FSV ISFSI Exposure Rates $(\mathrm{mR} / \mathrm{d}) \quad$. $\quad . \quad$. $\quad . \quad$. $\quad$. 2

2. FSV ISFSI Airborne Tritium Monitoring Results $(\mu \mathrm{Ci} / \mathrm{cc}) . \quad$. . 3 


\section{Annual Radiological Environmental Monitoring Program Report for the Fort St. Vrain Independent Spent Fuel Storage Installation}

\section{INTRODUCTION}

The Fort St. Vrain (FSV) Independent Spent Fuel Storage Installation (ISFSI) is a spent fuel dry storage facility located in Platteville, Colorado. The FSV ISFSI is operated by Bechtel BWXT Idaho, LLC for the Department of Energy (DOE). The FSV ISFSI is licensed (SNM-2504) by the Nuclear Regulatory Commission (NRC) pursuant to 10 CFR 72 for authorization to store spent nuclear fuel from the Fort St. Vrain Nuclear Generating Station. ${ }^{1}$ Spent fuel from the FSV reactor was transferred to the FSV ISFSI between December 26, 1991 and June 10, 1992. The FSV ISFSI license was transferred from the Public Service Company of Colorado (PSCo) to the U.S. Department of Energy, Idaho Operations Office (DOE-ID) on June 4, 1999. A Radiological Environmental Monitoring Program (REMP) has been implemented for the FSV ISFSI in accordance with 10 CFR 72.44. This report presents the REMP results for 2003.

\section{PROGRAM DESCRIPTION}

The REMP is designed to monitor the predominant radiation exposure pathway inherent with the facility design: direct radiation. The direct radiation exposure pathway is monitored using thermoluminescent dosimetry (TLD) located along the 100 meter perimeter fence of the FSV ISFSI. Monitoring locations are identified in Figure 1. A control station is located at the Weld County Sheriff Office in Greeley, Colorado, approximately 17 miles NNE from the FSV ISFSI. Twenty TLDs are located around the 100 meter perimeter fence to monitor direct radiation from the FSV ISFSI. One third of the TLDs are changed out and processed each month.

Figure 1. FSV ISFSI Radiological Environmental Monitoring Locations

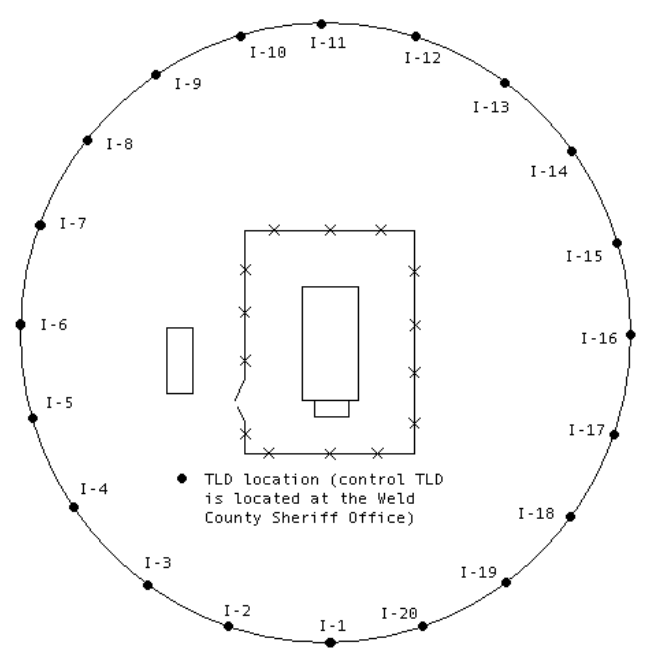


Molesieve samples are collected periodically within the ISFSI chimney and charge face and are subsequently analyzed for tritium radioactivity, but this is not considered part of the REMP.

\section{RESULTS}

TLD results for the FSV ISFSI are presented in Table 1 in units of $\mathrm{mR} / \mathrm{d}$. Dosimetry processing services were provided by the INEEL. The mean daily exposure rate of $0.38+/-0.01 \mathrm{mR} / \mathrm{d}$ measured at the ISFSI perimeter fence is not significantly different than the five-year historical operation mean of 0.39 +/- $0.05 \mathrm{mR} / \mathrm{d}$ last reported by Colorado State University (CSU). ${ }^{2}$ Previous annual REMP reports (preceding 1999) have indicated that the historical operation mean exposure rates were not significantly above preoperational and background levels for eastern Colorado.

Although not considered to be a monitoring location, a TLD is located at the control station in Greeley, CO, approximately 17 miles NNE from the FSV ISFSI. The results show the mean exposure rates at the control station to be $0.36+/-0.05 \mathrm{mR} / \mathrm{d}$.

Table 1. FSV ISFSI Exposure Rates (mR/d)

\begin{tabular}{|c|c|c|c|c|c|c|c|c|c|c|c|c|c|}
\hline Location & JAN & FEB & MAR & APR & MAY & JUN & JUL & AUG & SEP & OCT & NOV & DEC & Mean \\
\hline $\mathrm{I}-1$ & 0.40 & - & - & 0.49 & - & - & 0.31 & - & - & 0.38 & - & - & 0.40 \\
\hline $\mathrm{I}-2$ & - & 0.41 & - & - & 0.41 & - & - & 0.31 & - & - & 0.40 & - & 0.38 \\
\hline $\mathrm{I}-3$ & - & - & 0.38 & - & - & 0.41 & - & - & 0.34 & - & - & 0.38 & 0.38 \\
\hline $\mathrm{I}-4$ & 0.38 & - & - & 0.49 & - & - & 0.32 & - & - & 0.37 & - & - & 0.39 \\
\hline I-5 & - & 0.42 & - & - & 0.41 & - & - & 0.32 & - & - & 0.38 & - & 0.38 \\
\hline $\mathrm{I}-6$ & - & - & 0.39 & - & - & 0.40 & - & - & 0.32 & - & - & 0.36 & 0.37 \\
\hline $\mathrm{I}-7$ & 0.38 & - & - & 0.45 & - & - & 0.30 & - & - & 0.36 & - & - & 0.37 \\
\hline $\mathrm{I}-8$ & - & 0.42 & - & - & 0.40 & - & - & 0.32 & - & - & 0.38 & - & 0.38 \\
\hline I-9 & - & - & 0.39 & - & - & 0.40 & - & - & 0.35 & - & - & 0.38 & 0.38 \\
\hline $\mathrm{I}-10$ & 0.38 & - & - & 0.49 & - & - & 0.31 & - & - & 0.36 & - & - & 0.39 \\
\hline $\mathrm{I}-11$ & - & 0.42 & - & - & 0.42 & - & - & 0.33 & - & - & 0.39 & - & 0.39 \\
\hline I-12 & - & - & 0.38 & - & - & 0.40 & - & - & 0.33 & - & - & 0.39 & 0.38 \\
\hline $\mathrm{I}-13$ & 0.37 & - & - & 0.42 & - & - & 0.30 & - & - & 0.38 & - & - & 0.37 \\
\hline $\mathrm{I}-14$ & - & 0.41 & - & - & 0.40 & - & - & 0.32 & - & - & 0.39 & - & 0.38 \\
\hline $\mathrm{I}-15$ & - & - & 0.39 & - & - & 0.39 & - & - & 0.34 & - & - & 0.40 & 0.38 \\
\hline I-16 & 0.38 & - & - & 0.49 & - & - & 0.31 & - & - & 0.37 & - & - & 0.39 \\
\hline $\mathrm{I}-17$ & - & 0.41 & - & - & 0.40 & - & - & 0.32 & - & - & 0.39 & - & 0.38 \\
\hline I-18 & - & - & 0.39 & - & - & 0.38 & - & - & 0.34 & - & - & 0.38 & 0.38 \\
\hline I-19 & 0.37 & - & - & 0.45 & - & - & 0.31 & - & - & 0.38 & - & - & 0.38 \\
\hline $\mathrm{I}-20$ & - & 0.42 & - & - & 0.41 & - & - & 0.32 & - & - & 0.41 & - & 0.39 \\
\hline Mean & 0.38 & 0.42 & 0.39 & 0.47 & 0.41 & 0.40 & 0.31 & 0.32 & 0.34 & 0.37 & 0.39 & 0.38 & 0.38 \\
\hline Control & 0.36 & 0.38 & 0.36 & 0.45 & 0.39 & 0.39 & 0.26 & 0.28 & 0.33 & 0.33 & 0.38 & 0.35 & 0.36 \\
\hline
\end{tabular}

Although not part of the REMP, the vault chimneys and charge face are sampled periodically for airborne tritium. The results are noted in Table 2. Charge face airborne radioactivity samples collected during the fourth quarter indicated an average tritium concentration of $1.8 \mathrm{E}-12 \mu \mathrm{Ci} / \mathrm{cc}$ in 2003 . 
Table 2. FSV ISFSI Airborne Tritium Monitoring Results $(\mu \mathrm{Ci} / \mathrm{cc})$.

\begin{tabular}{lcccc}
\hline \multicolumn{2}{c}{ Q1 } & Q2 & Q3 & Q4 \\
\hline Location & & & & \\
North Charge Face & $<7.41 \mathrm{E}-13$ & $<1.75 \mathrm{E}-12$ & $<1.43 \mathrm{E}-12$ & $1.69 \mathrm{E}-12$ \\
South Charge Face & $<1.28 \mathrm{E}-12$ & $<1.15 \mathrm{E}-12$ & $<1.63 \mathrm{E}-12$ & $1.71 \mathrm{E}-12$ \\
East Charge Face & $<1.25 \mathrm{E}-12$ & $<1.27 \mathrm{E}-12$ & $<1.16 \mathrm{E}-12$ & $1.92 \mathrm{E}-12$ \\
West Charge Face & $<1.04 \mathrm{E}-12$ & $<1.52 \mathrm{E}-12$ & $<1.00 \mathrm{E}-12$ & $1.82 \mathrm{E}-12$ \\
& & & & - \\
Chimney A & - & $<1.06 \mathrm{E}-12$ & - & - \\
Chimney B & - & $<1.65 \mathrm{E}-12$ & - & - \\
Chimney C & - & $<1.07 \mathrm{E}-12$ & - & - \\
Chimney D & - & $<1.70 \mathrm{E}-12$ & - & - \\
Chimney E & - & $<1.05 \mathrm{E}-12$ & - & - \\
Chimney F & - & $<1.75 \mathrm{E}-12$ & & - \\
\hline
\end{tabular}

\section{DISCUSSION}

The FSV ISFSI REMP was successfully implemented during 2003. There was no loss of radiological monitoring data. There were no sampling location changes. There were no deviations from the established sampling schedule. The dosimeters associated with the April values in Table 1 did appear to have been exposed to a radiation source on their return shipment to the INEEL for processing ${ }^{3}$. The radiation dosimetry results indicate there has been no measurable increase in ambient background radiation levels outside the FSV ISFSI perimeter fence attributed to storage of the FSV fuel. There were no radioactive liquid effluents released from the facility, hence no radionuclides to report.

The positive airborne tritium monitoring results are attributed to the characteristic spring and fall removal of tritium from the atmosphere associated with the relocation of the jet stream and some other weather phenomena. ${ }^{4}$

\section{CONCLUSION}

Direct radiation exposure from the facility during 2003 did not contribute to any increase in the maximum potential dose commitment to the nearest resident $(0.15 \mathrm{mrem} / \mathrm{y})$ projected in the FSV ISFSI Safety Analysis Report. ${ }^{5}$

\section{REFERENCES}

1. $\quad 10$ CFR 72, "Licensing Requirements for the Independent Storage of Spent Nuclear Fuel and High-Level Radioactive Waste", Code of Federal Regulations, Office of the Federal Register, August 1988.

2. Fort St. Vrain Independent Spent Fuel Storage Installation (ISFSI) Radiological Environmental Monitoring Program (IREMP), Summary Report for the Period January 1 to December 31, 1997 , Department of Radiological Health Sciences, Colorado State University, February 26, 1998. 
3. G. G. Hall, Statistical Evaluation of Suspect FSV ISFSI Environmental Dosimetry Results, letter GGH-11-03, May 13, 2003.

4. "Tritium in the Atmosphere and Ocean", H. Gote Ostlund, Published in Tritium, Edited by A. Alan Moghissi and Melvin W. Carter, May 1973.

5. Fort St. Vrain Independent Spent Fuel Storage Installation Safety Analysis Report, Section 7.5, Estimated Offsite Collective Dose Assessment. 